\title{
Rheumatoid Arthritis Revealed by Myocardial Infarction in a Type 1 Diabetic Patient
}

\author{
Maissa Thabet*, Asma Ben Abdelkrim, Safa Khaldi, Ghada Saad, Maha Kacem, Molka Chaieb, Amel Maaroufi, \\ Yosra Hasni and Koussay Ach
}

Endocrinology Department, University of Sousse, Tunisia

Submission: March 20, 2021; Published: April 07, 2021

*Corresponding author: Maissa Thabet, Endocrinology department, Farhat Hached Hospital, University of Sousse, Faculty of medicine of Sousse, 400 , Sousse, Tunisia

\section{Abstrcat}

The association of rheumatoid arthritis (RA), Hashimoto thyroiditis and type 1 diabetes mellitus (T1D) is rarely reported. Herein, we report the case of a sixty-year old female, with a history of non-complicated type 1 diabetes and well-substituted Hashimoto thyroiditis who had a myocardial infarction at the age of 48 year-old. Our patient did not have classical risk factors for coronary heart disease, clinical and laboratory investigations showed the diagnosis of rheumatoid arthritis. The association of RA and the autoimmune endocrinopathies is not a fortuitous finding and coronary disease in well equilibrated T1D patient should encourage physician to search another aetiology.

Keywords: Rheumatoid arthritis; Type 1 diabetes; Myocardial infarction

\section{Introduction}

The association of rheumatoid arthritis (RA) and type 1 diabetes mellitus (T1D) is rarely reported [1-4]. These two diseases belong to different clusters of autoimmune diseases. Recent studies have shown that patients with T1D have a higher risk of developing RA [5]. Both diabetes and RA are risk factors for coronary heart disease. Their association potentially increase this risk. In this paper, we report a case of RA revealed by coronary heart disease in a patient with the history of non-complicated T1D and primary hypothyroidism.

\section{Patient and Observation}

Regarding her family history, her sister was followed for type 1 diabetes and there was nocardiovascular history For her personal medical history, she is treated for T1D (anti-GAD antibodies> $2000 \mathrm{IU} / \mathrm{ml}$ ) for 27 years complicated by diabetic retinopathy, and for Hashimoto's thyroiditis (Anti-TPO antibodies $>500 \mathrm{UI} / \mathrm{ml}$, anti-TG antibodies $>1000 \mathrm{UI} / \mathrm{ml}$ ) for 13 years. At the age of 48-year-old, fifteen years after the diagnosis of diabetes and 2 years after the diagnosis of hypothyroidism, which is well balanced on replacement therapy and in the absence of classic cardiovascular risk factors she had a myocardial infarction in the anterior territory requiring thrombolysis and placement of 2 coronary stents.
Clinically, she was complaining of paresthesias of the lower extremities, polyarthralgia of the small joints with morning stiffness evolving since 5 months. Her blood pressure was correct. Her body mass index is $27 \mathrm{~kg} / \mathrm{m}^{-2}$. On examination, she had free joints without arthritis. The hands X-ray did not show any abnormalities Biochemical testing revealed an elevated HbA1c: 8\%, a creatinine level at $66 \mu \mathrm{mol} / \mathrm{l}$ with a normal microalbuminuria: $12.5 \mathrm{mg} / 24 \mathrm{~h}$. The lipid balance did not show any abnormalities: triglyceride: $1.3 \mathrm{mmol} / \mathrm{l}$,HDL: Cholesterol: $0.5 \mathrm{~g} / \mathrm{l}$, LDL cholesterol: 0,8g/l. Sedimentation rate was raised to 62. Her thyroid workup was normal with a TSH: $3.5 \mathrm{UI} / / \mathrm{L}$. Immunological assessment revealed the positivity of rheumatoid factors and anti-cyclic citrullinated peptide antibodies (anti-CCP).

\section{Discussion}

$\mathrm{RA}$ is an autoimmune disease with anti citrullinated peptides reactivity and chronic inflammation which can leads to joint destruction. It is a long-term autoimmune disorder that primarily affects joints. It typically results in warm, swollen, and painful joints. Its cardiac involvement is rarely reaveling the disease. T1D is also caused by autoimmune to pancreatic $\beta$ cells destruction. The association of Hashimoto thyroiditis, T1D and juvenile rheumatoid arthritis is also reported [9-11]. To our knowledge, 
this is the first case associating T1D, Hashimoto thyroiditis and RA revealed by a coronary artery disease in an adult.

In most reported patients - similar to our case - diabetes was diagnosed first, thyroid autoimmunity and rheumatoid arthritis developed after a period of several months to years. This clustering suggests that these diseases might share a common genetic background [12]. Although the exact aetiology of RA and T1D are unknown, it is likely due to a combination of genetic susceptibility and interactions between environmental risk factors and genes. The association between T1D and RA is also reported, especially before the diagnosis of RA [13] and mechanism for this association may include shared genetic predisposition. [14] Interestingly, parents with RA are also more likely to have children with type 1 diabetes [15].

In fact, Inheritance of HLA-DR3 or DR4 antigens increases risk for the development of T1D. Individuals with DR3or DR4 have also an increased risk for developing RA and particularly the severe seropositive forms [16,17]. Thus, both DR3 and DR4 confer increased risk in both conditions. Moreover, the antiCCP antibodies have been presented as reliable and specific novel markers indicative of future RA development. They have generated particular interest in terms of predicting the appearance of disease in selected groups of patients with other autoimmune diseases [18]. However, the association between adult type $1 \mathrm{DM}$ and RA remains controversial and especially in the context of anti-CCP antibody positivity. Liao KP and al, in their case-control study including 1401 adult patients provided evidence of a specific and significant association between T1D and RA among anti-CCP positive patients with an odds ratio of 7.3 [14]. Katherine P and al suggest that part of this association could be attributed to the presence or effect of the 620W PTPN22 allele, which corroborates with previous studies demonstrating that the PTPN22 polymorphism is a risk factor for T1D as well as for anti-CCP positive RA [3,19,20]. However, other authors [21,22] reported the rarity of anti-CCP antibody positivity among adult patients with T1D. When the myocardial infarction occurred, our patient had a high cardiovascular risk as her diabetes duration is more than 10 years but without any cardiovascular risk factors and with well replaced peripheral hypothyroidism, this prompted us to search another aetiology. The risk of atherosclerotic disease is increased in RA. Coronary artery disease is more common in RA patients, with higher mean coronary calcium score, more multivascular disease, and more high-risk plaques compared to controls [23]. Carotid artery intima-media thickness and reduced brachial artery flow-mediated vasodilatation was also reported to be increased in RA patients [24,25].

Patients with RA have a reduced life expectancy when compared with the general population. Cardiovascular death is responsible for approximately half of the deaths observed in RA cohorts [26]. In fact, This disease is associated with increased risk of myocardial infarction that is comparable to the risk in patients with type 2 diabetes $[27,28]$. The high risk of cardiovascular pathology in these patients is due to chronic inflammation and autoimmunity, which can lead to accelerated atherosclerosis [29]. Many mechanisms were proposed such as proinflammatory pathways (TNF-alpha, IL-6), adhesion molecules and cellular infiltrates, and endothelial dysfunction, which is the first step in atherosclerosis development [29].

The link between inflammation and cardiovascular risk was established in patients with RA. The Disease Activity Score or DAS-28 score, which is a score that assesses the activity of RA and includes markers of active inflammation (CRP levels, erythrocyte sedimentation rates, numbers of affected joints), has been linked to cardiovascular risk [30].

\section{Conclusion}

The finding of these autoimmune diseases in genetically susceptible individuals suggests that the association could be more than a coincidence. This case reports a rare association of three autoimmune disorders. This association of RA and the autoimmune endocrinopathies is not a fortuitous finding and coronary disease in well equilibrated T1D patient should encourage physician to search another aetiology.

\section{Authors' Contributions}

All authors have contributed equally to this work.

\section{References}

1. Agrawal S, Desai MP (2003) Simultaneous occurrence of type I diabetes mellitus and juvenile rheumatoid arthritis. Indian Pediatr 40(6): 568571.

2. Munakata Y, Kodera T, Saito T, Sasaki T (2005) Rheumatoid arthritis, type 1 diabetes, and Graves disease after acute parvovirus B19 infection. Lancet 366(9487): 780.

3. Somers EC, Thomas SL, Smeeth L, Hall AJ (2006) Autoimmune diseases co-occurring within individuals and within families: a systematic review. Epidemiology 17(2): 202-217.

4. Zonana MF, Reyes E, Weisman AK (2002) Coexistence of four autoimmune diseases in one patient: the kaleidoscope of autoimmunity. J Clin Rheumatol 8(6): 322-325.

5. Kronzer VL, Crowson CS, Sparks JA, Myasoedova E, Davis JM $3^{\text {rd }}$ (2019) Comorbidities As Risk Factors for Rheumatoid Arthritis and Their Accrual After Diagnosis. Mayo Clin Proc 94(12): 2488-2498

6. Klareskog L, Catrina AI, Paget S (2009) Rheumatoid arthritis. Lancet 373(9664): 659-672.

7. Palmer JP, Asplin CM, Clemons P, Lyen K, Tatpati O, et al. (1983) Insulin antibodies in insulin-dependent diabetics before insulin treatment. Science 222(4630): 1337-1339.

8. Baekkeskov S, Aanstoot HJ, Christgau S, Reetz A, Solimena M (1990) Identification of the $64 \mathrm{~K}$ autoantigen in insulin-dependent diabetes as the GABA-synthesizing enzyme glutamic acid decarboxylase. Nature 347(6289): 151-156. 


\section{Current Research in Diabetes \& Obesity Journal}

9. Nagy KH, Lukacs K, Sipos P, Hermann R, Madacsy L, et al. (2010) Type 1 diabetes associated with Hashimoto's thyroiditis and juvenile rheumatoid arthritis: a case report with clinical and genetic investigations. Pediatr Diabetes 11(8): 579-582.

10. Mellos A, Mauro A, Di Meglio M (2011) Type 1 diabetes associated with Hashimoto's thyroiditis and juvenile rheumatoid arthritis: a case report. Pediatr Rheumatol 9: 34.

11. Fisher M, Nussbaum M, Abrams CA, Shenker IR (1980) Diabetes mellitus, Hashimoto's thyroiditis, and juvenile rheumatoid arthritis. Am J Dis Child 134(1): 93-94.

12. Criswell LA et al. (2005) Analysis of families in the multiple autoimmune disease genetics consortium (MADGC) collection: the PTPN22 620W allele associates with multiple autoimmune phenotypes. Am J Hum Genet 76: 561-571.

13. Comorbidities as Risk Factors for Rheumatoid Arthritis and Their Accrual After Diagnosis.

14. Liao KP, Gunnarsson M, Kallberg H (2009) Specific association of type 1 diabetes mellitus with anti-cyclic citrullinated peptide-positive rheumatoid arthritis. Arthritis Rheum 60: 653-660.

15. Hemminki K, Li X, Sundquist J, Sundquist K (2009) Familial association between type 1 diabetes and other autoimmune and related diseases. Diabetologia 52(9): 1820-1828.

16. Sachs JA, Brewerton DA (1978) HLA heterogeneity in diabetes arthritis. Br Med Bull 34: 275.

17. Panayi GS, Wooley P, Batchelor JR (1978) Genetic basis of rheumatoid disease: HLA antigens, disease manifestations and toxic reactions to drugs Br Med J 2: 1326

18. Avouac J, Gossec L, Dougados M (2006) Diagnostic and predictive value of anti-cyclic citrullinated protein antibodies in rheumatoid arthritis: a systematic literature review. Ann Rheum Dis 65(7): 845-851.

19. Plenge RM, Padyukov L, Remmers EF, Purcell S, Lee AT, et al. (2005) Replication of putative candidate-gene associations with rheumatoid arthritis in $>4,000$ samples from North America and Sweden: association of susceptibility with PTPN22, CTLA4, and PADI4. Am J Hum Genet 77(6): 1044-1060.
20. Kallberg H, Padyukov L, Plenge RM, Ronnelid J, Gregersen PK, et al. (2007) Gene-gene and gene-environment interactions involving HLADRB1, PTPN22, and smoking in two subsets of rheumatoid arthritis. Am J Hum Genet 80(5): 867-875.

21. Desplat-Jego S, Deharveng I, Baronne R, Valero R, Begu-Le Corroller A (2010) Antibodies to cyclic citrullinated peptides (anti-CCP) in Type 1 diabetes mellitus. Diabet Med 27(6): 725-727.

22. Yıldız M, İșleten F, Demir K, Celik N, Korkmaz HA (2016) Anti-cyclic citrullinated peptide antibodies are not frequently observed in children with type 1 diabetes mellitus: a single-center study. Turk J Pediatr 58(4): 395-399.

23. Hansen PR, Feineis M, Abdulla J (2019) Rheumatoid arthritis patients have higher prevalence and burden of asymptomatic coronary artery disease assessed by coronary computed tomography: A systematic literature review and meta-analysis. Eur J Intern Med 62: 72-79.

24. Wang P, Guan SY, Xu SZ, Li HM, Leng RX, et al. (2016) Increased carotid intima media thickness in rheumatoid arthritis: an update metaanalysis. Clin Rheumatol 35(2): 315-323.

25. Di Minno MN, Ambrosino P, Lupoli R, De Minno A, Tasso M, et al. (2015) Clinical assessment of endothelial function in patients with rheumatoid arthritis; a metaanalysis of literature studies. Eur J Clin Med 26: 835-842.

26. Goodson N (2002) Coronary artery disease and rheumatoid arthritis. Curr Opin Rheumatol 14(2): 115-120.

27. Nurmohamed MT, Heslinga M, Kitas GD (2015) Cardiovascular comorbidity in rheumatic diseases. Nat Rev Rheum 11: 693-704.

28. Lindhardsen J, Ahlehoff O, Gislason GH, Madsen OR, Olesen JB, et al. (2011) The risk of myocardial infarction in rheumatoid arthritis and diabetes mellitus - A Danish nationwide cohort study. Ann Rheum Dis 70: 929-934.

29. Prasad M, Hermann J, Gabriel SE, Weyand CM, Mulvagh S, et al. (2015) Cardiorheumatology: Cardiac involvement in systemic rheumatic disease. Nat. Rev. Cardiol 12(3): 168-176.

30. Liang KP (2009) Autoantibodies and the risk of cardiovascular events. J Rheumatol 36(11): 2462-2469.

Your next Submission with Juniper Publishers
will reach you the below assets
- Quality Editorial service
- Swift Peer Review
- Reprints availability
- E-prints Service
- Manuscript Podcast for convenient understanding
- Global attainment for your research
- Manuscript accessibility in different formats
( Pdf, E-pub, Full Text, Audio)
- Unceasing customer service
Track the below URL for one-step submission
https://juniperpublishers.com/online-submission.php

